Acta Universitatis Nicolai Copernici • Pedagogika XLII/2/2021

Nauki Humanistyczno-Społeczne • Zeszyt 454

DOI: http://dx.doi.org/10.12775/AUNC_PED.2021.016

\author{
Justyna Wojniak \\ Wydział Nauk Społecznych \\ Uniwersytet Pedagogiczny im. Komisji Edukacji Narodowej \\ w Krakowie \\ ORCID: 0000-0002-6158-1115
}

\title{
KOMPARATYSTYKA EDUKACYJNA
}

W PERSPEKTYWIE FILOZOFICZNEJ:

Sergiusz Hessen (1887-1950)

I JEGO PODEJŚCIE DO BADAŃ

PORÓWNAWCZYCH W PEDAgOGICE

Comparative education in a philosophical view:

Sergiusz Hessen (1887-1950) and his approach

to comparative research in education

\begin{abstract}
Streszczenie
Sergiusz Hessen, filozof i pedagog, to postać, która zajmuje ugruntowane miejsce w historii myśli pedagogicznej, a centralnym punktem jego twórczości stała się koncepcja naukowego statusu pedagogiki jako filozofii stosowanej. Celem artykułu jest przybliżenie innego, istotnego obszaru zainteresowań badawczych tego uczonego, jaki stanowiła komparatystyka edukacyjna. Wydaje się to uzasadnione o tyle, że dorobek tego uczonego z zakresu badań porów-
\end{abstract}


nawczych jest nakreślony w dość ogólny sposób lub jedynie zasygnalizowany¹. We wprowadzeniu do artykułu zaprezentowano krótki zarys biografii Hessena, ważny z punktu widzenia badań, jakie prowadził. W dalszej części znajduje się charakterystyka jego koncepcji pedagogiki jako filozofii stosowanej, a następnie uwaga została skoncentrowana na prowadzonych przez tego uczonego badaniach z obszaru komparatystyki pedagogicznej. Zastosowana na potrzeby artykułu analiza treści prac Hessena o charakterze porównawczym oraz dostępnych materiałów wskazujących na ich międzynarodowy odbiór, pozwalają na sformułowanie wniosku, że w osobie Sergiusza Hessena mamy do czynienia z jednym z pierwszych w Europie uczonych, który sposób systematyczny prowadził badania porównawcze systemów edukacyjnych, a jego prace wraz z dorobkiem Józefa Chałasińskiego, Zygmunta Mysłakowskiego czy Bogdana Nawroczyńskiego tworzyły zręby polskiej komparatystyki edukacyjnej.

Słowa kluczowe: filozofia, kultura, wychowanie, systemy edukacyjne, pedagogika porównawcza.

\section{Abstract}

Sergiusz Hessen, a philosopher and educator, is a figure who has a well-established place in the history of pedagogical thought, and the concept of the scientific status of pedagogy as applied philosophy became the focal point of his work. The aim of the article is to present another important area of his research interests, namely comparative education. A number of studies on Hessen's scientific work in the field of comparative research present his achievements in a fairly general manner or include only short remarks on this topic. The introduction to this paper presents a short outline of Hessen's biography, which is important from the point of view of his research. The following is a description of his concept of pedagogy as an applied philosophy, and then the attention is focused on his research conducted in the field of comparative education. This leads to the conclusion that Sergiusz Hessen can be consi-

${ }^{1}$ Zob. m. in.: T. Nowacki, Wstęp. Sergiusz Hessen - 1887-1950 w: S. Hessen, Filozofia - kultura - wychowanie, Wrocław-Warszawa-Kraków-Gdańsk 1973, W. Okoń, Sergiusz Hessen jako człowiek $i$ uczony, w: S. Hessen, Podstawy pedagogiki, Warszawa 1997, A. Walicki, Stowo wstępne w: S. Hessen, Studia z filozofii kultury, Warszawa 1968. 
dered as one of the first European researchers who systematically conducted comparative studies of educational systems, and his works, along with the achievements of JózefChałasiński, ZygmuntMysłakowski and Bogdan Nawroczyński, formed the foundations of Polish comparative education.

Key w ords: philosophy, culture, education, education systems, comparative education.

\section{Wprowadzenie. Sergiusz Hessen: w poszukiwaniu swojego miejsca $w$ życiu i w nauce}

„Wędrowiec” (wanderer) - takiego określenia dla opisania postaci Sergiusza Hessena używają Ryszard Kucha i Mariola Świderska w poświęconym temu badaczowi artykule. W jego tytule znajduje się też zwięzła charakterystyka Hessena: twórczy europejski pedagog bez ojczyzny (creative European educationalist with no homeland) ${ }^{2}$. Jak bardzo trafne wydaje się to stwierdzenie, pokazuje pobieżna nawet analiza skomplikowanej drogi życiowej Sergiusza Hessena, w której nie brak dramatycznych wydarzeń i zmian krajów zamieszkania. Podobnie jest również w przypadku dziedzin, które Hessen poddawał naukowej eksploracji - jakkolwiek zasadniczym przedmiotem jego zainteresowań badawczych była filozofia, swoje badania prowadził także w dziedzinie pedagogiki, prawa czy językoznawstwa ${ }^{3}$.

Hessen urodził się 1887 roku w Ust'-Sysolsku (obecnie miasto to nosi nazwę Syktywkar), na terenie autonomicznej republiki Komi, gdzie jego ojciec przebywał na zesłaniu w związku ze swoją polityczną aktywnością, którą zajmował się we wczesnej młodości ${ }^{4}$. Po upływie okresu ze-

${ }^{2}$ R. Kucha, M. Świderska, Sergiusz Hessen (1887-1950) - as creative European educationalist with no homeland, „Journal of Intercultural Management” 2013, Vol. 5, No. 4, p. 81-82.

3 T. Nowacki, Wstęp. Sergiusz Hessen - 1887-1950 w: S. Hessen, Filozofia kultura - wychowanie, Wrocław-Warszawa-Kraków-Gdańsk 1973, s. VII-XI.

${ }^{4}$ S. Hessen, Moje życie w: S. Hessen, Pisma pomniejsze, Wyd. „Żak”, Warszawa 1997, s. 11. W późniejszym okresie swojego życia ojciec Hessena, Józef Władymirowicz nie rezygnował z działalności politycznej - współtworzył Partię Konstytucyjno-Demokratyczną, zwaną partią kadetów (Zob. B. Nawroczyński, Sergiusz 
słania, ojciec Sergiusza dokończył przerwane studia prawnicze i podjął karierę w wyuczonym zawodzie. Sergiusz Hessen wychowywał się w Odessie, gdzie trafił w wieku pięciu lat i zamieszkał z drugą żoną ojca i trzema jej synami - z najmłodszym ze swoich przybranych braci uczęszczał do tej samej klasy w Pierwszym Sankt-Petersburskim Gimnazjum $^{5}$. Obydwaj przystąpili też do egzaminu magisterskiego na Wydziale Historyczno-Filologicznym Uniwersytetu Petersburskiego ${ }^{6}$. Jeszcze $\mathrm{w}$ okresie nauki w gimnazjum Hessen zaangażował się w prace redakcyjne w wydawanym przez jego ojca prawniczym tygodniku pod tytułem „Prawo”, co, jak sam podkreśla w swojej autobiografii „miało wielkie znaczenie dla mego wykształcenia i wyrobienia stylu"7.

Po maturze Hessen wyjechał do Heidelbergu, gdzie na tamtejszym uniwersytecie podjął studia filozoficzne i uczęszczał na wykłady $\mathrm{m}$. in. Windelbanda i Jellinka. W Heidelbergu poznał też swoją przyszłą żonę Ninę Miron ${ }^{8}$. Ostatnie sześć semestrów swoich studiów spędził w uniwersytecie we Fryburgu, gdzie zetknął się z Heinrichem Ricker-

Hessenw: Polski słownik biograficzny, t. IX, Zakład Narodowy im. Ossolińskich, Wyd. Naukowe Polskiej Akademii Nauk, Wrocław-Warszawa-Kraków 1960-1961, s. 487).

${ }^{5}$ Jak podaje T. Nowacki we wstępie do pracy Hessena pod tytułem Filozofia kultura - wychowanie, Sergiusz Hessen egzamin dojrzałości zmuszony był zdawać na prowincji, z uwagi na swoją współpracę z działaczem socjalistycznym, współpracownikiem Lenina i teoretykiem marksizmu, Georgijem Plechanowem, którego przez pewien czas był sekretarzem. W carskiej Rosji zamknęło to Hessenowi drogę do matury w petersburskim gimnazjum (Zob. T. Nowacki, dz. cyt., s. V). Sam Hessen nie wspomina o tym fakcie w swojej autobiografii, a postać Plechanowa pojawia się tam w kontekście poglądów politycznych autora i rozmów, które niedługo przed jego śmiercią Hessen z nim przeprowadził po jego powrocie do kraju z emigracji, gdzie Plechanow przebywał w latach 1880-1917. Z uwagi na to, że maturę Hessen zdawał w 1905 roku, a Plechanow wrócił do Rosji w 1917 roku, funkcja Hessena jako sekretarza Plechanowa wydaje się nieuprawdopodobniona. Być może Nowacki ma na myśli aktywność publicystyczną Hessena, realizowaną w piśmie „Jedność” („Jedinstwo”), związanym z założonym przez Plechanowa ugrupowaniem socjaldemokratycznym pod tą samą nazwą (Zob. S. Hessen, Moje życie..., s. 26-27).

${ }^{6}$ S. Hessen, Moje życie..., s. 12-13.

7 Tamże, s. 16.

8 Tamże, s. 18. 
tem i założeniami jego filozofii idealistycznej, które znacząco wpłynęły na poglądy Hessena9 . W 1909 roku uzyskał stopień doktora summa cum laudena na podstawie rozprawy Individuelle Kausalität (O przyczynowości indywidualnej). Współpraca z Rickertem i kolegami ze studiów w ramach koła filozoficznego zaowocowała pomysłem stworzenia czasopisma filozoficznego - tak powstał wydawany później w Moskwie „Logos”, w którym publikowane były prace utrzymane w nurcie neokantyzmu ${ }^{10}$.

Po ukończeniu studiów w Niemczech Hessen znalazł się ponownie w Petersburgu, gdzie współtworzył Towarzystwo Przyjaciół Filozofii, wygłaszał odczyty, uczestniczył w dyskusjach i publikował na łamach „Logosu”. W 1911 roku zdecydował się na krótki pobyt we Fryburgu, uczestniczył tam w wykładach z geometrii analitycznej oraz z fizyki, angażował się również w działalność swojego dawnego koła filozoficznego. W tym czasie również ukazała się jego Filozofia kary ${ }^{11}$. Wspomnienia Hessena z tego okresu odnoszą się także do pewnych komplikacji w życiu prywatnym - uczony w swojej autobiografii przywołał postać Olgi Aleksandrowny Szor, deklarując przyjaźń, która „graniczyła z głęboką miłością" i której rezultatem miała być separacja z żoną. Jednakże Hessen w swoich wyznaniach stwierdził, że „nie miał serca porzucić" ani jej, ani swoich dzieci ${ }^{12}$.

Po powrocie do Petersburga, w 1913 roku uzyskał tytuł magistra, a w 1914 roku objął w uniwersytecie funkcję wolnego docenta. W momencie wybuchu I wojny światowej Hessen przebywał z rodziną w Heidelbergu, gdzie został zatrzymany jako jeniec cywilny, a do Petersburga powrócił dopiero pod koniec 1914 roku. Wojenne losy kolegów Hessena spowodowały, że swoją działalność zakończyło pismo „Logos”, którego po wojnie nie udało się już reaktywować. Sam Hessen okres wojny spędził w Carskim Siole, kontynuując karierę wykładowcy uni-

9 B. Nawroczyński, Sergiusz Hessen w: Polski słownik biograficzny, t. IX, Wrocław-Warszawa-Kraków 1960-1961, s. 487.

10 S. Sztobryn Sergiusz Hessenw: Encyklopedia pedagogiczna XX wieku, t. II, Warszawa 2003, s. 192.

11 S. Hessen, Moje życie..., s. 21.

12 Tamże, s. 22. 
wersyteckiego, a także zdobywając doświadczenia dydaktyczne jako nauczyciel $\mathrm{m}$. in. w jednym z petersburskich gimnazjów. W tym samym czasie podjął wykłady z historii pedagogiki, która to dziedzina była dla niego „ziemią całkowicie nieznaną”, zabrał się więc „poważnie do jej studiowania”. Wydaje się, że w ten dość przypadkowy sposób odnalazł swoją naukową drogę: „Po dwu latach nie miałem już bynajmniej wrażenia, że zająłem się czymś, co nie było moją sprawą"13.

Tuż przed wybuchem rewolucji w 1917 roku Hessen wraz z rodziną wyjechał do Tomska - decyzja ta podyktowana była sytuacją materialną rodziny i warunkami życia w Petersburgu oraz nadziejami Hessena, że da mu to możliwość poświęcenia większej ilości czasu na pracę naukową. W kolejnych latach pełnił on funkcję dziekana wydziału historyczno-filologicznego na tamtejszym uniwersytecie, który na skutek wydarzeń politycznych przyciągał wybitnych wykładowców z różnych części Rosji, a także i z zagranicy. W Tomsku właśnie Hessen nawiązał znajomość z naukowcami z Polski, m. in. z A. Śmieszkiem, egiptologiem, oraz R. Dyboskim, anglistą. Jak sam podkreśla w swojej autobiografii: „Tomsk pozostawił jednak niezatarte ślady na moim rozwoju jako naukowca. Tutaj ukształtował się ostatecznie mój system pedagogiczny"14. W Podstawach pedagogiki zawarł treści, które były przedmiotem jego niezwykle drobiazgowo przygotowywanych wykładów.

Sytuacja polityczna w Rosji i obawa, że „w warunkach coraz mocniej dokręcanej śruby dyktatury"15 działalność naukowa i poglądy Hessena na cele wychowania czy kierunki reform szkolnictwa mogą doprowadzić do konfliktu z władzami, po krótkim pobycie w Petersburgu za namową ojca Hessen wraz z rodziną zdecydował się na wyjazd do Finlandii, a następnie do Berlina. Tam, razem $\mathrm{z}$ innymi rosyjskimi uczonymi z przyczyn politycznych wydalonymi z kraju, podjął współpracę z Rosyjskim Instytutem Naukowym. Również w Berlinie ukazały się jego Podstawy pedagogiki ${ }^{16}$.

\footnotetext{
13 Tamże, s. 25.

14 Tamże, s. 31.

15 Tamże, s. 33.

16 Tamże, s. 36.
} 
Kolejnym punktem na życiowej i naukowej drodze Hessena stała się Praga, gdzie osiedlił się w 1924 roku. Zaangażował się tam w działalność Rosyjskiego Instytutu Pedagogicznego, gdzie otrzymał stanowisko profesora, współpracował też z Uniwersytetem Niemieckim. Dużo $\mathrm{w}$ tym czasie publikował, m.in. prace na temat Dostojewskiego i Tołstoja. Często bywał również z odczytami za granicą, także w Polsce. Ważnym wydarzeniem $\mathrm{w}$ jego naukowym rozwoju stała się znajomość z Kerschensteinerem, na którego zaproszenie wygłosił w Wiesbaden odczyt pod tytułem Państwo i szkoła w Anglii i Francji ${ }^{17}$. Niewątpliwie uznać to należy za ważny krok w kierunku zainteresowania Hessena badaniami porównawczymi w pedagogice.

W trakcie pobytu w Pradze, Hessen po raz kolejny trafił w wir wydarzeń politycznych, które nie pozostały bez wpływu na jego naukową działalność: „krecia robota niemieckich narodowych socjalistów coraz bardziej dawała się odczuć w życiu politycznym i uniwersyteckim"18. Sytuacja ta oraz likwidacja Rosyjskiego Instytutu Pedagogicznego skłoniły go ku decyzji o wyjeździe do Polski. Propozycja ta pojawiła się podczas pobytu Hessena na Międzynarodowym Kongresie Wychowania Moralnego w Krakowie w 1934 roku $^{19}$. Dwa lata później Hessen po przyjeździe do Polski objął Katedrę Pedagogiki w Wolnej Wszechnicy Polskiej. Współpracował też z Uniwersytetem Warszawskim i Instytutem Pedagogiki Specjalnej - z dużym uznaniem wypowiadał się o polskich uczonych, Helenie Radlińskiej i Marii Grzegorzewskiej: „Obydwu tym znakomitym działaczkom oświatowym, które dzieliły się ze mną swym doświadczeniem życiowym, zawdzięczam rozszerzenie widnokręgu nie tylko jako teoretyk pedagogiki, ale także jako człowiek"20. Warto dodać, że znajomość z Radlińską zaowocowała poznaniem przez Hessena jej uczennicy, która pomagała mu w nauce języka polskiego i konsultowała z nim swoje prace socjologiczne - Maria Niemyska została jego drugą żoną ${ }^{21}$.

\footnotetext{
17 T. Nowacki, dz. cyt., s. VII.

18 S. Hessen, Moje życie..., s. 43.

19 T. Nowacki, dz. cyt., s. VII.

20 S. Hessen, Moje życie..., s. 47.

21 Tamże, s. 46.
} 
Już w Polsce, w 1939 roku, ukazało się jedno z kluczowych dzieł Hessena pod tytułem O sprzecznościach $i$ jedności $w$ wychowaniu, w znaczącym stopniu poświęcone wychowaniu moralnemu. Drugą, napisaną już w całości po polsku pracą, była Struktura i treść szkoły współczesnej, wydrukowana niedługo przed wybuchem II wojny światowej - do rąk czytelników trafiło jednak dopiero jej drugie wydanie, które ukazało się po wojnie ${ }^{22}$.

Wybuch II wojny światowej nie ograniczył działalności pedagogicznej Hessena, jako że bardzo intensywnie zaangażował się on w tajne nauczanie. Jednym z uczestników tajnych jego kompletów był działacz harcerski Aleksander Kamiński, autor Kamieni na szaniec, później najbliższy współpracownik i doktorant Hessena w Uniwersytecie Łódz$\mathrm{kim}^{23}$. W okresie wojny Hessen nie zaniedbywał też pracy naukowej, powstały wówczas jego Filozofia religijna u Dostojewskiego oraz Cnoty platońskie i ewangeliczne, pracował także nad książką Pozorne i rzeczywiste przezwyciężenie kapitalizmu oraz nad Istota i powołaniem prawa.

Mimo zaangażowania w tajne nauczanie i związanego z tym ogromnego ryzyka, Hessenowi udało się uniknąć aresztowania. Jednakże wybuch powstania warszawskiego, mimo docierających do niego od uczniów informacji o planowanych działaniach, zupełnie go zaskoczył. Zniszczenia w obrębie miasta nie ominęły także mieszkania Hessena, który w wyniku pożaru stracił wszystkie rękopisy swoich książek i notatki do publikacji, nad którymi wówczas pracował. Taki sam los spotkał złożone u wydawców kopie prac uczonego ${ }^{24}$.

Okres do końca wojny Hessen wraz z żoną spędził u mieszkającej w Czeladzi siostry żony - obydwoje udzielali tam lekcji grupie dziewczynek. Jeszcze przed zakończeniem wojny Hessen wyjechał do Łodzi na zaproszenie rektora Wolnej Wszechnicy Polskiej, Teodora Viewegera. W Uniwersytecie Łódzkim podjął wykłady z zakresu pedagogiki, a później także historii filozofii i filozofii prawa.

Mimo tragicznych wiadomości o śmierci najbliższych, m.in. starszego syna i jego matki, a także ojca i jednego z przybranych braci, Hes-

\footnotetext{
22 T. Nowacki, dz. cyt., s. IX.

23 S. Hessen, Moje życie..., s. 57.

24 Tamże, s. 61.
} 
sen kontynuował pracę naukową. Z tego okresu pochodzą m.in. prace, które ukazały się za granicą: Slavonic Countries (1948) oraz Education and Economic Life (1949). Na zamówienie UNESCO napisał równieżThe Rights of Man in Liberalism. Socialism and Communism (1949).

Krytyczny stosunek Hessena do kierunku przemian politycznych w powojennej Polsce i reform prowadzonych w duchu stalinizmu w znaczącym stopniu utrudniał mu funkcjonowanie na stanowisku kierownika Katedry Pedagogiki w łódzkiej uczelni. Względy ideologiczne szybko przesądziły o utracie przez niego tej funkcji. Hessen nie rezygnował jednak z pracy naukowej i dydaktycznej i mimo posiadanego już znaczącego dorobku i pozycji w środowisku naukowym, zdecydował się podjąć badania i zajęcia ze studentami w nowej dziedzinie, a mianowicie w obszarze filologii rosyjskiej ${ }^{25}$. Do tego zadania był niewątpliwie znakomicie przygotowany, jako że wcześniej studiował tę dziedzinę i publikował rozprawy poświęcone $\mathrm{m}$. in. Tołstojowi czy Dostojewskiemu. Starał się również łączyć ten nowy obszar badań z dziedziną, którą zgłębiał na wcześniejszym etapie swojej naukowej drogi, a mianowicie z filozofią. Swoim analizom lingwistycznym nadawał wyraźny rys filozoficzny, osadzał je także na gruncie estetyki, szczególnie w odniesieniu do archaicznych konstrukcji językowych ${ }^{26}$.

Aktywny w pracy naukowej Sergiusz Hessen pozostał mimo pogarszającego się stanu zdrowia, prowadząc wykłady i odczyty. Ostatni wygłosił w Uniwersytecie Mikołaja Kopernika w Toruniu na kilka dni przed swoją śmiercią w 1950 roku.

\section{Pedagogika jako filozofia stosowana}

Jak już zostało zaznaczone, skomplikowany splot okoliczności, jakie wywarły wpływ na życiowe i zawodowe decyzje Sergiusza Hessena, doprowadził tego uczonego do podjęcia systematycznych badań w dziedzinie pedagogiki. Jako że wyrósł on niejako z dyscypliny, jaką

25 W. Okoń, Sergiusz Hessen jako człowiek i uczony w: S. Hessen, Podstawy pedagogiki, Warszawa 1997, s. 18.

26 A. Walicki, Stowo wstępne w: S. Hessen, Studia z filozofii kultury, Warszawa 1968, s. 18. 
była filozofia, miał też możliwość uczenia się od kilku wybitnych jej przedstawicieli, naturalny kierunek poszukiwań odpowiedzi na pytania dotyczące wychowania i kształcenia wyznaczała mu właśnie filozofia. Jak wskazuje Sławomir Sztobryn w swojej pracy na temat filozofii wychowania Hessena, przedstawienie doktryny pedagogicznej tego badacza w oderwaniu od analizy jego filozoficznych poglądów skutkowałoby niewłaściwą jej interpretacją i niosło z sobą ryzyko sformułowania błędnych wniosków ${ }^{27}$.

Jako punkt wyjścia dla rozważań na temat naukowego statusu pedagogiki warto przyjąć stanowisko Hessena przedstawione w pracy O sprzecznościach i jedności wychowania. Zagadnienia pedagogiki personalistycznej ${ }^{28}$. Hessen jednoznacznie wskazał tu, że nie jest możliwe rozpatrywanie nauki o wychowaniu jako autonomicznej lub też „czystej”. Dowodził jednocześnie, że treścią tej nauki jest rozbudzanie w człowieku wartości kulturalnych i jego „wrastanie w ducha obiektywnego", co stanowi przedmiot nauk filozoficznych. W procesie wychowania zatem kluczowy staje się sposób traktowania tych wartości, który z kolei warunkowany jest ogólną postawą filozoficzną. Stąd też błędne jest założenie, że w procesie tym możliwe jest zdystansowanie się od filozoficznego "stanowiska” czy „poglądu na świat”29.

W tym samym tomie autor krytycznie odniósł się do pozytywistycznego przekonania o potrzebie poddania się ludzkości panowaniu obiektywnej nauki. Podobnie traktował kantyzm z jego przekonaniem o możliwości oddzielenia mającego walor subiektywizmu światopoglądu, tkwiącego w psychicznych predyspozycjach jednostki i społecznych warunkach jej egzystencji, od filozofii, która na fundamencie naukowym opiera to, co wspólne dla całej ludzkości, jednocząc jej wysiłki w dążeniu do prawdy, dobra i piękna ${ }^{30}$. Tymczasem wszystkie „duchowe" wytwory ludzkości, nie tylko filozofia czy religia, ale również

27 S. Sztobryn, Filozofia wychowania Sergiusza Hessena, Łódź 1994, s. 18-19.

28 S. Hessen, O sprzecznościach i jedności wychowania. Zagadnienia pedagogiki personalistycznej, Książnica-Atlas, Lwów-Warszawa 1939, s. 110.

29 Tamże, s. 110-111.

30 Tamże, s. 14-15. (Zob. S. Hessen, Istota i znaczenie poglądu na świat, „Kultura i Wychowanie" 1933, Rok I, Zeszyt I, s. 9). 
sztuka i nauka noszą na sobie piętno światopoglądu. To światopogląd staje się dla człowieka źródłem świadomości swojego umiejscowienia w bycie, a jednocześnie stanowi dla jednostki swoisty punkt oparcia ${ }^{31}$. Z drugiej strony zaś to światopogląd stanowi impuls do podejmowania prób wyjścia poza swoje jednostkowe ,ja” i do „wchłonięcia w siebie wszechświata i przezwyciężenia swojej odrębności" tak, by konstruowana w ten sposób osobowość odzwierciedlała uniwersalny i obiektywny świat kultury ${ }^{32}$.

Czy w związku z tym jest zatem możliwe i pożądane, by szkoła była instytucją światopoglądowo neutralną? Jak podkreślał Hessen, „Zadanie kształcenia polega więc na tym, aby człowiek zdobył sobie światopogląd i dzięki temu stał się osobowością"33. Proces ten łączyć należy z „duchową atmosferą", w której dziecko dorasta. Nauczyciel ze swoją osobowością staje się kluczowym elementem środowiska, w jakim młody człowiek egzystuje, a zatem nawet jeśli wykłada przedmiot ścisły, co pozornie nie pozostawia przestrzeni na uzewnętrznianie własnych poglądów, w dalszym ciągu pozostaje przedstawicielem danego stanowiska. Co więcej, taka postawa w procesie wychowawczym jest wręcz pożądana, ponieważ nauczyciel, który stara się zachować dystans i stwarzać pozory obiektywizmu, niczego wartościowego nie jest w stanie swoim uczniom przekazać, bo będzie unikał odpowiedzi na nurtujące uczniów życiowe pytania. Stąd potrzeba znalezienia przez nauczycieli i wychowawców złotego środka, a więc odrzucenia z jednej strony „obojętnej neutralności”, a z drugiej narzucania uczniom własnego światopoglądu „w formie gotowej ideologii, która jest wyższa ponad wszelką dyskusję i występuje jako nieskazitelny dogmat"34. W rezultacie mamy do czynienia z karykaturą pedagogiki, która przybiera kształt ideologiczno-politycznej pedagogiki totalnej, z jej odtwórczym sposobem uczenia się i nauczaniem według określonego, nie podlega-

31 S. Hessen, Studia z filozofii kultury, Warszawa 1968, s. 88.

32 S. Hessen, O sprzecznościach i..., s. 37-38.

33 Tamże, s. 55.

34 Tamże, s. 62. 
jącego kwestionowaniu wzoru ${ }^{35}$. Właściwie pojmowany proces kształcenia powinien być ukierunkowany na dojrzewanie w człowieku osobowości i „otwieranie” jego światopoglądu. Warunkiem realizacji tego zadania przez wychowawcę jest gotowość do „samoprzezwyciężenia” własnego poglądu na świat i odrzucenie żądzy władania: „Jak tolerancja cechuje wszelką działalność kształcącą, tak fanatyzm charakteryzuje propagandę, która jest mechaniczną deprawacją kształcenia"36.

Kluczową wartością w pedagogice powinna zatem stać się refleksja i rodzaj dialogu między zróżnicowanymi światopoglądami - chodzi o to, by nie ulec konkretnemu stanowisku, ale by potraktować je z pewną dozą krytycyzmu, wynikającego z konfrontacji z innymi światopoglądami. Droga do pokonania światopoglądowego uwikłania i uniknięcia pokusy narzucania danego stanowiska wychowankom prowadzi poprzez samoświadomość i refleksję, platońskie „zdanie sprawy”, co stanowi przecież podstawowe zadanie filozofii. Dzięki przyjęciu takiej zasady postępowania, pedagogika „rozszerza swój duchowy widnokrąg i tym bardziej staje się pedagogiką filozoficzną"37.

Dla ilustracji bliskich związków pedagogiki jako teorii kształcenia i filozofii, uzewnętrzniających się w uznaniu pedagogiki za filozofię stosowaną, Hessen przywołał argument o tożsamości przedmiotu obydwu dziedzin. Są nim „wartości kulturalne, czyli życie duchowe, w którym realizują się te wartości"38. Pedagogika ma przy tym do odegrania rolę praktyczną, polegającą na badaniu struktury tych wartości oraz ocenie poziomu rozwoju życia duchowego jako kryterium efektywności realizacji celów i zadań kształcenia. Warto zaznaczyć, że tych celów i zadań Hessen nie traktował w kategoriach normatywnych, koncentrował bowiem swoją uwagę na „realnym wzroście życia duchowego”, a więc zakładał, że mamy tu do czynienia z dynamicznym procesem,

35 W. Mikołajewicz, Dlaczego pedagogika filozoficzna? O filozoficznych podstawach pedagogiki w myśli Sergiusza Hessena w: Wokót idei pedagogicznych Sergiusza Hessena, red. A. Wróbel,. M. Błędowska, Łódź 2013, s. 24.

36 S. Hessen, Pogląd na świat a pedagogika, „Kultura i Wychowanie” 1934, Rok I, Zeszyt II, s. 129-133.

37 S. Hessen, O sprzecznościach $i . . .$, s. 80.

38 Tamże, s. 127. 
swego rodzaju ewolucją, choć zapewne też i regresem, będącym pokłosiem „konkretnej, niepowtarzalnej sytuacji”. Stąd artykułowana przez niego niechęć do „sztucznej formuły normy”, norma bowiem jest regułą natury ogólnej, a tak pojmowane normy „podkopują naukowość praktyki pedagogicznej" 39 .

Tymczasem o dynamicznym, wymykającym się sztywnym regułom charakterze procesu kształcenia świadczy chociażby fakt, że jego cele i środki wzajemnie się warunkują, wymuszając pewną dozę elastyczności. Oznacza to, że w danym momencie zastosowanie określonego środka może wymusić modyfikację celu, środek zaś może stać się celem prowizorycznym. Z kolei osiągnięty na pewnym etapie cel, który wydawał się ostateczny, może przekształcić się w środek prowadzący do nowego celu, jaki wcześniej nie był brany pod uwagę, na przykład ze względu na ograniczone rozeznanie okoliczności. Cele wychowania nie stanowią więc zamkniętego katalogu o normatywnym charakterze, wskazującym, ,jak być powinno”, ale pozostają płynne, otwarte. Należy utożsamiać je z wartościami, których zespół składa się na kulturę: „Wychowanie nie jest niczym innym, jak kulturą jednostki. I jeżeli w stosunku do narodu kultura jest zespołem niewyczerpanych celów-zadań, to w stosunku do jednostki niewyczerpanym zadaniem jest wychowanie. Wychowanie, jak to wynika z jego istoty, nie może być nigdy zakończone"40.

Jak zauważa Andrea Folkierska, określenia „kultura” Hessen używał w odniesieniu do całościowego ujęcia świata, dla którego inspiracją stała się złożona z warstw struktura, jaką prezentuje Platon w swoim Państwie. Całości tej konstrukcji Hessen nadał miano wartości, a zatem kultura jako zespół wartości jest tożsama z celem wychowania, zaś proces wychowania to urzeczywistnianie tych wartości w konkretnych jednostkach ${ }^{41}$. Mimo że mamy tu do czynienia z kategorią wartości, co mogłoby implikować ich uniwersalny czy niezmienny charakter, Hessen zaznaczył, że jakkolwiek należy wartości traktować jako kate-

39 Tamże, s. 128.

40 S. Hessen, Podstawy pedagogiki, Warszawa 1997, s. 75.

41 A. Folkierska, Sergiusz Hessen - pedagog odpowiedzialny, Warszawa 2005, s. 67. 
gorię ponadczasową, to walor ten dotyczy tylko faktu ich obowiązywania, a nie treści: „Ponadczasowe wartości nie stanowią bynajmniej czegoś gotowego i raz na zawsze danego"42. Tym samym skłaniał się ku stanowisku, że wartość jako taka nie istnieje, a obowiązuje, co należy rozumieć, że nie wymusza na jednostce zachowania się w określony, narzucony sposób, ale staje się czynnikiem wymagającym reakcji: jej przyjęcia lub odrzucenia.

Jednostka zachowuje więc swobodę decyzji co do tego, jak do danej wartości się ustosunkuje. Zasadne w tym kontekście staje się rozróżnienie między wolnością negatywną i pozytywną. $\mathrm{O}$ ile ta pierwsza zabezpiecza jednostkową możliwość dokonania wyboru i uwzględnienia bądź odrzucenia danej wartości, a więc wolność od wszelkiego rodzaju zewnętrznej presji, o tyle wolność pozytywna to wolność do, polegająca na dobrowolnym przyjęciu na siebie zobowiązań wynikających z akceptacji danej wartości ${ }^{43}$.

Warunkiem urzeczywistnienia tych dwóch aspektów wolności staje się więc gotowość jednostki do podjęcia wysiłku zmierzającego do zajęcia określonego stanowiska wobec wartości, a następnie do konsekwentnego działania ukierunkowanego na jej realizację. Zaangażowanie twórczych sił jednostki wokół urzeczywistnienia danej wartości uruchamia rozwój jej osobowości, czyli „ducha podmiotowego”. Jego nieodłączną cechą staje się samowiedza niezbędna do ustosunkowania się wobec świata zarówno zewnętrznego, jak i wewnętrznego, a więc refleksja, pod wpływem której kształtuje się indywidualny światopogląd. W tym procesie pomóc ma jednostkom odpowiednia organizacja działań, jaką jest wychowanie. Celem i istotą wychowania staje się więc wprowadzenie w świat wartości kulturowych ${ }^{44}$. Jak zaznaczał Hessen w swoich Podstawach pedagogiki, pedagogika odbija w sobie rozwój myśli filozoficznej, natomiast w dziejach wychowania odbija się z kolei rozwój kultury w jej całości: „zagadnienie wychowanie jest zagadnieniem kultury"45.

42 S. Hessen, Podstawy..., s. 190.

43 S. Hessen, Szkoła i demokracja na przełomie, Warszawa 1997, s. 234.

44 T. Nowacki, dz. cyt., s. XXIII.

45 S. Hessen, Podstawy..., s. 77. 
Z tych pozycji Hessen krytycznie wypowiadał się na temat pracy Józefa Chałasińskiego pod tytułem Szkoła $w$ społeczeństwie amerykańskim, która ukazała się w 1936 roku. W swoim artykule na jej temat podniósł problem „socjologizmu”, w ramach którego za istotną słabość rozważań Chałasińskiego uważał uznanie przez tego autora szkoły za „bierny odbiornik wpływów ze strony najrozmaitszych grup społecznych”. Skutkuje to zawężeniem perspektywy badawczej, która „zupełnie ignoruje rolę szkoły jako nosiciela kultury duchowej narodu"46.

\section{Badania porównawcze w pedagogice}

Rozważania Hessena na temat filozoficznego ugruntowania pedagogiki i znaczenia kultury w procesie wychowawczym niejako w naturalny sposób doprowadziły do wyartykułowania przez niego przekonania, że tłem dla analizy systemu wychowawczego danej epoki i dominujących w niej prądów pedagogicznych zawsze będzie „koloryt czasu”"47. Tym samym poszczególne cele wychowania będą zdominowane przez jeden, wiodący, stanowiący punkt odniesienia, wokół którego formuje się kulturalna świadomość epoki. Założenie to Hessen zilustrował przywołaniem średniowiecznej teokracji z jej religijnym systemem wychowania, etatystycznych tendencji starożytnego Rzymu i determinowanym przez nie wychowaniem w duchu podporządkowania się państwu i prawu jako naczelnym wartościom czy też oświeceniowego priorytetu rozumu znajdującego również swoje odzwierciedlenie w intelektualistycznym systemie wychowania.

Swoim podejściem Hessen wpisał się w fundamentalne z punktu widzenia edukacyjnej komparatystyki stanowisko, w zwięzły, acz trafny sposób zaprezentowane przez jednego z najwybitniejszych przedstawicieli tej dziedziny badań, Michaela Sadlera, który w jednej ze swoich najczęściej cytowanych wypowiedzi zauważył, że „to, co dzieje się poza szkołą znaczy dla zrozumienia systemu wychowania nawet więcej niż to, co ma miejsce w szkole, regulując i wyjaśniając to, co dzieje się we-

46 S. Hessen, O niebezpieczeństwie socjologizmu $w$ pedagogice w: S. Hessen, Pisma pomniejsze, Warszawa 1997, s. 181.

47 S. Hessen, Podstawy..., s. 77. 
wnątrz"48. W badaniach czołowych komparatystów pedagogicznych to właśnie czynniki określane mianem „duchowej siły narodu” czy „narodowego koloru, zapachu i kształtu" wysuwają się na plan pierwszy $\mathrm{W}$ analizie porównawczej systemów edukacyjnych ${ }^{49}$. W tym kierunku podążał w swoich badaniach również Hessen, który nie ograniczył się do prostego zestawiania z sobą systemów wychowawczych, ale podjął próbę ukazania specyfiki zjawisk i faktów edukacyjnych na tle kulturowego układu, w jakim mają one miejsce. Wymagało to nie tylko pogłębionej wiedzy, ale i ogromnej ostrożności w formułowaniu wniosków, bez której łatwo byłoby popaść w pułapkę uproszczeń i kulturowych schematów. Hessenowi udało się tej pułapki uniknąć, w czym z pewnością pomogło mu wszechstronne wykształcenie i samodzielna eksploracja różnych dziedzin nauki, ale i doświadczenia wynikające z życia i pracy w zróżnicowanych kulturowo środowiskach.

Za pierwsze wyczerpujące dzieło pedagogiczne o charakterze porównawczym uznawana jest cytowana już praca Hessena nosząca tytuł Szkoła i demokracja na przełomie (1937). Jest to zbiór szkiców, w których autor omawia ,zarówno nowe eksperymenty szkolne, jak i szkolne prawodawstwo oraz nową ideologię pedagogiczną" ${ }^{2}$. W tym opracowaniu Hessen zaprezentował kształcenie i wychowanie w kilku wybranych krajach europejskich: Anglii, Francji, Czechosłowacji i w Polsce. W każdym ze szkiców szczegółowo nakreślił wspomniane kulturowe tło systemu wychowania, determinujące poszczególne rozwiązania w obrębie tego systemu. I tak przykładowo w przypadku Anglii wiele uwagi autor poświęcił sięgającej XIV wieku tradycji, jako że "pedagogika angielska, jak żadna inna, przesiąknięta jest duchem tradycji”51.

Typowo porównawczy charakter, polegający na zestawieniu dwu systemów, przybrał kolejny z jego szkiców, poświęcony Francji i Anglii,

48 M. E. Sadler, How far can we learn anything of practical value from the study of foreign systems of education? w: G. Z. F. Bereday, Sir Michael Sadler's Study of Foreign Systems of Education, "Comparative Education Review” 1964, Vol. 7, No. 3, p. 309-310.

49 I. L. Kandel, Essays in comparative education, New York 1930, p. 3.

50 S. Hessen, Szkoła i ..., s. 11.

51 Tamże, s. 137. 
którego zasadniczy wątek dotyczył roli państwa i wpływu jego instytucji na funkcjonowanie i rozwój szkolnictwa w obydwu krajach. Na zasadzie kontrastu autor zaprezentował wdrażaną we francuskiej organizacji oświaty „zasadę państwową” w opozycji do angielskiej „zasady wolności"52.

Rozdziały poświęcone Czechosłowacji i Polsce, a więc krajom, w których Hessen mieszkał, skoncentrowane zostały przede wszystkim na reformach edukacyjnych. Było to podyktowane sytuacją polityczną obu państw, które przez długi okres swojej historii nie stanowiły samodzielnych bytów politycznych i administracyjnych, w związku z czym zmuszone były do budowania od podstaw narodowych systemów edukacyjnych. W obydwu krajach za priorytet autor uznał demokratyzację systemu szkolnictwa (szkoła jednolita), która stanowiła warunek „skierowania nieuniknionego procesu podniesienia się mas na uporządkowane drogi wolnego, samorządnego społeczeństwa"53.

Niewątpliwym walorem tej pracy jest to, że autor nie ograniczył się wyłącznie do analizy stanu faktycznego, ale starał się odnieść do projektów reform, odzwierciedlających dynamikę przemian, jakie miały miejsce w obrębie danego systemu. Została tu więc także podjęta próba wskazania kierunku, w jakim potencjalnie systemy te będą ewoluować.

W Szkole i demokracji na przełomie mamy jednak do czynienia z ujęciem porównawczym nie tylko w odniesieniu do konkretnych systemów edukacyjnych, ale również z pogłębioną analizą współczesnych Hessenowi koncepcji pedagogicznych, które zaliczyć można do nurtu progresywizmu czy też Nowego Wychowania (Kerschensteiner, Dewey). Autor odniósł się również do poglądów włoskich pedagogów: Giuseppe Lombardo-Radice i Giovanniego Gentile. W przypadku tego ostatniego dał wyraz swojemu rozczarowaniu jego entuzjazmem wobec faszyzmu: „jego racjonalny ideał pedagogiczny stał się łupem irracjonalnych potęg życia"54. Unikał jednak sformułowania jednoznacznej opinii o włoskim systemie edukacji, jako że na analizowanym etapie nie można było poddać weryfikacji efektów polityki edukacyjnej w tym kraju.

\footnotetext{
52 Tamże, s. 174.

53 Tamże, s. 302.

54 Tamże, s. 265.
} 
Jak sam Hessen deklarował, mimo odmiennej niż wcześniej przez niego poruszana tematyki, $\mathrm{w}$ dalszym ciągu pozostawał on filozofem. Zastanawiał się bowiem co prawda nad konkretnymi zjawiskami, umieszczonymi w danym czasie i miejscu, jednak poprzez uwzględnienie kierunków reform próbował nadać im trwalszy charakter, wybiegając niejako w przyszłość. Z kolei zakorzenienie faktów edukacyjnych w sferze szeroko pojętej kultury również nadawało im wymiar ponadczasowy: „staram się sprowadzić te zjawiska do zasad ponadczasowych, stanowiących przedmiot rozważań filozoficznych"55.

Perspektywa porównawcza widoczna jest również w rozważaniach Hessena na temat pożądanego modelu szkoły, która ma wychowywać młodych ludzi w duchu wolności i samorządności. Jest nią wspomniana już w kontekście reform edukacyjnych w Czechosłowacji i Polsce szkoła jednolita. Za jej zadanie uznał zapoznawanie uczniów z wartościami kultury i rozwijanie na tym fundamencie ich wolnej i niezależnej osobowości w duchu solidarności, równości szans i społecznej sprawiedliwości ${ }^{56}$.

Demokratyczny model szkoły jednolitej, gwarantującej równy dostęp dla wszystkich zaczął upowszechniać się w pierwszych dekadach XX wieku, mimo widocznego w wielu krajach zachodniej Europy oporu ze strony konserwatywno-liberalnych kręgów. Przezwyciężenie tych tendencji zaowocowało wprowadzeniem w szeregu krajów określonych przepisów prawa - Hessen odwoływał się do regulacji przyjętych w poszczególnych krajach, jak Anglia, Szwajcaria czy Związek Radziecki. Naukowa uczciwość nakazywała mu także dostrzec w tym gronie państwa faszystowskie, które jednakże wprowadziły w dostępie do kształcenia ograniczenia o charakterze narodowościowym. Analiza Hessena prezentuje przyjmowane przez omawiane państwa rozwiązania w zakresie obowiązku szkolnego, organizacji procesu kształcenia czy treści nauczania, w tym elastycznych programów kształcenia itp. W oparciu o pochodzące $\mathrm{z}$ różnych krajów informacje i dane Hessen sformułował schemat odzwierciedlający współczesne mu tenden-

55 Tamże, s. 11.

56 S. Hessen, Struktura i treść szkoły wspótczesnej. Zarys dydaktyki ogólnej, Warszawa 1997, s. 13-14. 
cje rozwojowe w szkolnictwie w kontekście koncepcji szkoły jednolitej, scharakteryzował również warunki niezbędne dla jej realizacji ${ }^{57}$.

Uwidacznia się $\mathrm{w}$ ten sposób w rozważaniach Hessena praktyczna rola, jaką badaniom porównawczym przypisują komparatyści. Już bowiem w początkowej fazie usystematyzowanych badań porównawczych w edukacji, jeden z ich prekursorów, Marc Antoine Jullien de Paris wskazywał na korzyści płynące z gromadzenia danych na temat wychowania i kształcenia w poszczególnych krajach. Odwoływanie się do zagranicznych doświadczeń i eksperymenty czy reformy wzorowane na przyjętych za granicą rozwiązaniach mogły bowiem stanowić drogę do doskonalenia rozwiązań edukacyjnych u siebie i zwiększania efektywności procesu kształcenia, co przełożyć się miało na dobrobyt państw i dobrostan ich obywateli ${ }^{58}$.

Metoda porównawcza została wykorzystana przez Hessena również w analizie dotyczącej edukacji w Rosji radzieckiej. Praca zatytułowana Pedagogika i szkolnictwo $w$ Rosji sowieckiej powstała w 1932 roku we współpracy z Nicholasem (w polskim tłumaczeniu książki występującym jako Mikołaj) Hansem, jednym z najbardziej znanych XX-wiecznych komparatystów edukacyjnych, doskonale zorientowanym w polityce edukacyjnej Rosji59.

W tomie tym, którego oryginał napisany w języku angielskim i wydany w 1930 roku, a następnie uzupełniony, autorzy omówili rozwój szkolnictwa radzieckiego i zmiany w polityce edukacyjnej, jakie dokonały się na przestrzeni lat 1917-1932, obejmującej okres od wybuchu rewolucji październikowej do zakończenia tzw. planu pięcioletniego $^{60}$. Opracowanie to ma wielowymiarowy i złożony charakter, a jego punktem wyjścia autorzy uczynili okres panowania carycy Katarzyny II Wielkiej, która, wierna ideałom Oświecenia, zainicjowała funkcjo-

57 Tamże, s. 63-67.

58 S. Fraser, Jullien's Plan for Comparative Education 1816-1817, New York 1964, p. 17-19.

59 J. Miąso, Szkolnictwo carskiej Rosji w świetle historiografii amerykańskiej i brytyjskiej, "Rozprawy z Dziejów Oświaty", t. XXXV/92, s. 118.

$60 \mathrm{~W}$ podtytule pracy zostało to doprecyzowane: Rozwój szkolnictwa sowieckiego i zmiany komunistycznej polityki oświatowej od rewolucji październikowej do końca planu pięciolecia (1917-1932). 
nowanie jednolitej szkoły demokratycznej, dostępnej przedstawicielom wszystkich stanów społecznych ${ }^{61}$. Natomiast na okres, którego dotyczy zasadnicza część rozważań autorów, przypadało wdrażanie komunistycznej idei szkoły, charakteryzującej się silnym naciskiem na rozwój kształcenia zawodowego. Ucieleśnieniem tej idei miało być wychowanie politechniczne, łączące $\mathrm{w}$ sobie naukę szkolną $\mathrm{z}$ "pracą społecznie wytwórczą" - orędowniczką tej koncepcji była Nadieżda Krupska ${ }^{62}$.

Politechnizacji procesu wychowania towarzyszyć miała sekularyzacja oraz koedukacja, a głębokie zmiany w profilu kształcenia miały zostać uzupełnione przez określone nastawienie ideologiczne. Cel edukacji polegał bowiem na wykreowaniu całkowicie nowego modelu obywatela: komunisty, członka bezklasowego społeczeństwa, a zasadniczą rolę w tym procesie odegrać miało wychowanie polityczne, adresowane przede wszystkim do dorosłej części społeczeństwa i realizowane poprzez sieć nieformalnych instytucji. Hessen nie krył swojego krytycznego nastawienia do obecności jakiejkolwiek ideologii w procesie wychowania, o czym była już mowa, nie może zatem dziwić jego negatywne nastawienie do tego rodzaju przedsięwzięć władz radzieckich w obszarze edukacji. Porównywał je zresztą do religijnie pojmowanej aktywności misjonarskiej, z tym że zastąpienie elementów religijnych politycznymi nadawało jej karykaturalną postać63.

Warto $\mathrm{w}$ tym miejscu dodać, że w duchu prezentowanego już przekonania Hessena, w procesie wychowania nie jest wskazane dystansowanie się przez wychowawcę od konkretnego światopoglądu w imię fałszywie pojmowanego obiektywizmu, badacz ten tak samo odnosił się do prowadzenia badań naukowych. W przedmowie do omawianego opracowania bowiem autorzy jednoznacznie zadeklarowali, że jakkolwiek ich poglądy polityczne i pedagogiczne dalekie są od komunizmu i marksizmu, nie jest ich celem ani stworzenie apologii sowieckiego szkolnictwa, ani też jego potępienie ${ }^{64}$. Aby jednak uniknąć zarzutów

61 S. Hessen, M. Hans, Pedagogika i szkolnictwo w Rosji sowieckiej, Lwów-Warszawa 1934, s. 11.

62 Tamże, s. 28-29.

63 Tamże, s. 214-217.

64 Tamże, s. 5. 
o brak naukowego podejścia do badanych zagadnień, przyjęli dość znamienne podejście metodologiczne. Mianowicie oparli swoje badania na analizie treści zawężonej wyłącznie do źródeł rodzimych dla przedmiotu badań, a więc dokumentów i materiałów, które powstały na terenie Związku Radzieckiego i zostały wytworzone przez urzędników i inne osoby odpowiedzialne za rozwój systemu edukacji oraz wdrażanie założeń polityki oświatowej państwa. Hessen i Hans uzasadnili to tym, że nie chcieli korzystać z opracowań zachodnich intelektualistów i badaczy, którzy w wielu wypadkach przejawiali bardzo pozytywny, graniczący wręcz z fascynacją, stosunek do Związku Radzieckiego ${ }^{65}$.

Warto dodać, że również w tym opracowaniu Hessen i Hans swoje rozważania na temat koncepcji radzieckiego systemu wychowania i jej ewolucji ulokowali na szerszym tle historycznych i politycznych przemian w kraju. Jak napisali: „przemiany staramy się tłumaczyć historycznie: nie z punktu widzenia samowystarczalnego niejako rozwoju pedagogicznego, lecz w związku z losami marksizmu w Związku Sowieckim w ogóle, a mianowicie na tle tych zdobyczy i rozczarowań, jakie potężny przebieg rewolucji rosyjskiej przyniósł partii, wyniesionej przezeń do władzy"66. Takim podejściem ich praca wpisuje się w koncepcję badań porównawczych w pedagogice I połowy XX wieku, którą reprezentowali czołowi jej przedstawiciele w osobach przywołanych już Michaela Sadlera czy Isaaca Kandela.

\section{Podsumowanie}

Z zaprezentowanego rysu biograficznego wyłania się niewątpliwie postać człowieka o niezwykle szerokich horyzontach intelektualnych i chłonnym umyśle. Potwierdza to zdolność Hessena do adaptowania się do życia i pracy naukowej w kilku krajach, w czym z pewnością pomocna była wyniesiona z domu rodzinnego znajomość języków obcych,

65 A. Włoch, J. Wojniak, Global Field, Local Approach - 20 th Century Polish Education Comparativists and Their Works, SHS Web of Conferences 2019, Vol. 66, https://www.shs-conferences.org/articles/shsconf/abs/2019/07/shsconf_ erpa2019_01031/shsconf_erpa2019_01031.html (Dostęp: 27.05.2021).

66 S. Hessen, M. Hans, Pedagogì̄ka i szkolnictwo..., s. 11. 
ale i otwartość umysłu, jaką zawdzięczał intelektualnej atmosferze panującej w jego rodzinie. Nie bez znaczenia było też jego zamiłowanie do literatury pięknej, które rodzice kształtowali w nim od czasów dzieciństwa $^{67}$. Zaangażowanie polityczne, jakie przejawiał już we wczesnej młodości i sympatie lokowane po stronie socjaldemokracji czyniły go wrażliwym na problemy społeczne, jednakże, jak sam deklarował, jego niechęć do rewolucyjnych posunięć w tym obszarze dyktowana była „niepoprawnym ciążeniem ku zachodowi i liberalizmem demokratycznym, traktującym podejrzliwie wszelkie przejawy populizmu"68.

Uwagę zwraca też szerokie spektrum zainteresowań Hessena. Jak się wydaje, nie chodzi tu jedynie o zainteresowania czysto zawodowe, jako że w młodości uczestniczył w wykładach z matematyki, fizyki czy geometrii analitycznej, co z pewnością dalekie było od zasadniczego nurtu jego prac, jakim była filozofia. Zakładać można, że kształcenie $w$ tych dziedzinach miało być elementem intelektualnego rozwoju i umożliwić Hessenowi prowadzenie jego naukowych analiz z wielu zróżnicowanych perspektyw, zapewniających wyczerpujący i krytyczny ogląd danego zagadnienia. Ta niezwykła wszechstronność i gruntowna wiedza z różnych obszarów stanowiły fundament, dzięki któremu również praca naukowa Hessena nie ograniczała się wyłącznie do jednej dziedziny. O jego intelektualnej klasie świadczą pogłębione rozważania pedagogiczne o charakterze porównawczym, wymagające gruntownej znajomości historii, politycznych i społecznych realiów czy kultury krajów, których systemy edukacyjne analizował. Takie interdyscyplinarne podejście w przypadku Hessena nie jest jednak niczym zaskakującym, biorąc pod uwagę fakt, że był on także autorem prac z dziedziny prawoznawstwa, literatury czy językoznawstwa.

W tym kontekście nasuwa się refleksja, że prace Hessena z dziedziny komparatystyki edukacyjnej pozostają niejako w cieniu jego rozważań filozoficznych dotyczących pedagogiki. Ten obszar badań zasługuje jednak na wyeksponowanie, a także na bardziej pogłębioną analizę, jako że rzetelny materiał badawczy, jakim posługiwał się Hessen w swoich badaniach porównawczych, a także refleksje i wnioski,

67 S. Hessen, Moje życie..., s. 15-16.

68 Tamże, s. 26. 
jakie formułował, umożliwiają odbiorcy nie tylko prześledzenie ważniejszych tendencji w polityce oświatowej omawianych krajów czy okresów historycznych. Pozwalają również zrozumieć mechanizmy nimi rządzące i motywy, dla których władze wprowadzały określone przepisy i rozwiązania w obrębie swoich systemów edukacyjnych. Jest to szczególnie interesujące $\mathrm{w}$ kontekście przedmiotu zainteresowania Hessena. Były nim bowiem kraje znajdujące się w przełomowym momencie historycznym, jak Polska czy Czechosłowacja w początkowej fazie swojej niepodległości, bądź poddane silnej presji polityczno-ideologicznej, jak Rosja pod rządami bolszewików czy faszystowska Italia. Hessen w oparciu o te okoliczności bardzo wnikliwie diagnozował całkowicie odmienne cele, jakie determinowały kierunki polityki oświatowej tych państw. Z jednej strony można tu bowiem było mówić o kształceniu obywatela demokratycznego państwa, aktywnie włączającego się w rozwijanie niepodległej państwowości, a z drugiej - o kreowaniu „nowego człowieka”, komunisty czy faszysty, odpowiednio zindoktrynowanego i całkowicie poddanego totalitarnej władzy.

Badania porównawcze Hessena są również godne uwagi ze względu na jego wkład w rozwój tej dyscypliny w wymiarze międzynarodowym. Ważną rolę odegrała tu współpraca z Hansem, który podobnie jak Hessen urodził się w Rosji i wyemigrował do Anglii, a swoją karierę naukową realizował w King's College, gdzie wykładał pedagogikę porównawczą. Jednakże, co znamienne, w środowisku komparatystów panowało przekonanie, że to współpraca z Hessenem przyczyniła się do zwiększenia naukowej renomy Nicholasa Hansa ${ }^{69}$.

W światowym obiegu naukowym Hessen zaistniał również dzięki swoim opracowaniom dotyczącym szkolnictwa włoskiego, przyjętym z dużym zainteresowaniem w tym kraju, między innymi za sprawą Luigiego Volpicellego, który także zajmował się badaniami porównawczymi w pedagogice i współredagował ukazujący się co roku zbiór artykułów z zakresu komparatystyki edukacyjnej pod tytułem International Yearbook of Education, gdzie ukazywały się pisane w języku angielskim prace Hessena. Zarówno z Hansem, jak i z Volpicellim Hessen pozo-

${ }^{69}$ B. Holmes, Nicholas Hans [Obituary], "Comparative Education Review” 1970, Vol. 14, No. 1, p. 1. 
stawał w przyjaźni. Po jego śmierci Hans opublikował wspomnienie, w którym określił go jako humanistę, filozofa i pedagoga, znawcę problematyki edukacyjnej w krajach słowiańskich i badacza, który swoimi licznymi pracami opublikowanymi w dziesięciu językach, zyskał światowe uznanie ${ }^{70}$.

Jak zauważa sam Hessen w swojej autobiografii, absorbowało go wiele różnych projektów, przez co się rozpraszał, prezentował też lekkomyślny stosunek do niektórych przedsięwzięć badawczych, jak na przykład rozpoczęta tuż po zakończeniu studiów praca na temat filozofii Kanta, której rękopis spłonął w powstaniu warszawskim razem z innymi dziełami ${ }^{71}$. Godny uwagi jest jednak jego głód wiedzy $\mathrm{z}$ różnych dziedzin w połączeniu $\mathrm{z}$ etosem uczonego, jakiemu Hessen konsekwentnie hołdował, mimo zawirowań politycznych i osobistych tragedii, które go spotykały. W osobie Sergiusza Hessena mamy niewątpliwie do czynienia z postacią, do której dorobku warto sięgać i na nowo go odczytywać, konfrontując jego refleksje i spostrzeżenia ze zmieniającym się kontekstem działalności edukacyjnej.

\section{Bibliografia:}

Folkierska, Andrea, Sergiusz Hessen - pedagog odpowiedzialny. Warszawa: Wyd. Uniwersytetu Warszawskiego, 2005.

Fraser, Stewart, Jullien's Plan for Comparative Education 1816-1817. New York: Columbia University, 1964.

Hans, Nicholas, Sergius Hessen. „The Slavonic and East European Review”, Vol. 29, No. 72 (1950): 296-298.

Hessen, Sergiusz, Istota i znaczenie poglądu na świat. „Kultura i Wychowanie”, Rok I, Zeszyt I (1933): 9-29.

Hessen, Sergiusz, Moje życie w: Hessen, Sergiusz, Pisma pomniejsze. Warszawa: Wyd. „Żak”, 1997.

70 N. Hans, Sergius Hessen „The Slavonic and East European Review” 1950, Vol. 29, No. 72, p. 296.

71 S. Hessen, Moje życie..., s. 21-22. 
Hessen, Sergiusz, O niebezpieczeństwie socjologizmu w pedagogice, w: Hessen, Sergiusz, Pisma pomniejsze, Warszawa: Wyd. „Żak”, 1997.

Hessen, Sergiusz, O sprzecznościach i jedności wychowania. Zagadnienia pedagogiki personalistycznej, Lwów-Warszawa: Książnica-Atlas, 1939.

Hessen, Sergiusz, Podstawy pedagogiki Warszawa: Wyd. „Żak”, 1997.

Hessen, Sergiusz, Pogląd na świat a pedagogika. „Kultura i Wychowanie” 1934, Rok I, Zeszyt II (1934): 121-138.

Hessen, Sergiusz, Studia z filozofii kultury. Warszawa: Państwowe Wydawnictwa Naukowe, 1968.

Hessen, Sergiusz, Struktura i treść szkoły współczesnej. Zarys dydaktyki ogólnej. Warszawa: Wyd. „Żak”, 1997.

Hessen, Sergiusz, Szkoła i demokracja na przełomie. Warszawa: Wyd. „Żak”, 1997.

Hessen, Sergiusz, Hans, Mikołaj, Pedagogika i szkolnictwo w Rosji sowieckiej. Lwów-Warszawa: Książnica-Atlas, 1934.

Holmes, Brian, Nicholas Hans [Obituary]. „Comparative Education Review” 1970, Vol. 14, No. 1 (1970): 1.

Kandel, Isaac, Essays in comparative education. New York: Columbia University, 1930.

Kucha Ryszard, Świderska Mariola, Sergiusz Hessen (1887-1950) - as creative European educationalist with no homeland, „Journal of Intercultural Management", Vol. 5, No. 4, (2013): 81-92.

Miąso, Józef, Szkolnictwo carskiej Rosji w świetle historiografii amerykańskiej i brytyjskiej, „Rozprawy z Dziejów Oświaty”, t. XXXV (1992): 115-137.

Mikołajewicz, Wojciech, „Dlaczego pedagogika filozoficzna? O filozoficznych podstawach pedagogiki w myśli Sergiusza Hessena", w: Wokót idei pedagogicznych Sergiusza Hessena, red. Alina Wróbel, Magdalena Błędowska, 13-25, Łódź: Wyd. Uniwersytetu Łódzkiego, 2013.

Nawroczyński, Bogdan, Sergiusz Hessen w: Polski słownik biograficzny. t. IX, Wrocław-Warszawa-Kraków: Zakład Narodowy im. Ossolińskich, Wyd. Naukowe Polskiej Akademii Nauk, 1960-1961.

Nowacki, Tadeusz, Wstęp. Sergiusz Hessen - 1887-1950 w: Hessen, Sergiusz, Filozofia - kultura - wychowanie. Wrocław-Warszawa-Kraków-Gdańsk: Zakład Narodowy im. Ossolińskich, 1973. Okoń, Wincenty, Sergiusz Hessen jako człowiek i uczony w: Hessen, Sergiusz, Podstawy pedagogiki. Warszawa: Wyd. „Żak”, 1997.

Sadler, Michael E., How far can we learn anything of practical value from the study of foreign systems of education? w: George Z. F. Bereday, Sir Micha- 
el Sadler's Study of Foreign Systems of Education, „Comparative Education Review", Vol. 7, No. 3 (1964): 307-314.

Sztobryn, Sławomir, Filozofia wychowania Sergiusza Hessena. Łódź: Wyd. Uniwersytetu Łódzkiego, 1994.

Sztobryn, Sławomir, Sergiusz Hessenw: Encyklopedia pedagogiczna XX wieku. t. II, Warszawa: Wyd. Akademickie „Żak”, 2003.

Walicki, Andrzej, Stowo wstępne w: Hessen, Sergiusz, Studia z filozofii kultury. Warszawa: PaństwoweWydawnictwoNaukowe, 1968.

Włoch Anna, Wojniak, Justyna, Global Field, Local Approach $-20^{\text {th }}$ Century Polish Education Comparativists and Their Works, SHS Web of Conferences, Vol. 66 (2019): https://www.shs-conferences.org/articles/shsconf/ abs/2019/07/shsconf_erpa2019_01031/shsconf_erpa2019_01031.html. 